\title{
Magical Transition? Intergenerational Educational and Occupational Mobility in Rural China: 1988-2002 ${ }^{1}$
}

\author{
M. Shahe Emran \\ George Washington University and \\ IPD, Columbia University \\ Yan Sun \\ George Washington University \\ and IFPRI \\ Preliminary Draft: Comments Welcome
}

\begin{abstract}
This paper presents evidence on intergenerational educational and occupational mobility in Rural China over a period of 14 years (1988-2002). Since genetic correlations across children and their parents are not likely to change over such a short span of time, the coefficients on parents education and occupation in the multivariate regression analysis identify the direction of change in intergenerational persistence reasonably well. To understand if the estimated intergenerational persistence in a given year can be driven solely by unobserved genetic correlations, we take advantage of Altonji et al (2005) approach that uses selection on observables as a guide to selection on unobservables. The empirical results show that there has been dramatic improvements in occupational mobility from agriculture to non-farm occupations, a farmers children are not any more likely to become farmers in 2002. In contrast, the intergenerational persistence in educational attainment has remained strong over the span of 14 years, especially for sons. The results from sensitivity analysis and lower bound estimates show that it is unlikely that the observed educational persistence is driven solely by genetic correlations. We provide some possible explanations for the dramatic divergence between occupational and educational mobility in rural China from 1988 to 2002.
\end{abstract}

Key Words: Intergenerational Mobility, Occupational Choice, Educational Attainment, Economic Reform, Selection on Observables, Selection on Unobservables

\section{JEL Classification: O12, J62}

\footnotetext{
${ }^{1}$ We would like to thank John Giles, Alan DeBaruw, Stephen Smith, Dennis Yang for helpful discussions. The usual disclaimers apply. Emails for correspondence: shahe.emran@gmail.com, yansun2007@gmail.com
} 


\section{(1) Introduction}

The intergenerational transmission of economic status has been the focus of a growing literature in economics. ${ }^{2}$ There is now a substantial literature on developed countries that shows significant persistence of economic status across generations; the estimated partial correlation between income of parents and children falls in the range of 0.3 to 0.5 (see, Blanden et. al. (2005) and Solon (1999, 2002), Mazumder (2005)). In contrast, economic analysis of intergenerational mobility in the context of developing and transition countries remains a relatively little explored area of research; among the few available contributions are Lillard and Willis (1995) on Malaysia, Hertz (2001) on South Africa, Sato and Li (2007a, 2007b) on China, Emran and Shilpi (2011) on rural Nepal and Vietnam. ${ }^{3}$

In this paper, we analyze intergenerational economic mobility in rural China from 1988 to 2002 with special emphasis on possible gender differences. We are interested in understanding intergenerational economic persistence across the cross-section of the Chinese rural society in two different points of time almost a decade and half apart. The central question addressed in this paper is: if we compare two snapshots of the rural China in 1988 and 2002, has the Chinese rural society on an average become more or less mobile over time? ${ }^{4}$ In the absence of income or consumption data for parental generation, the empirical analysis focuses on educational and occupational persistence across generations. China is an interesting and important case study for understanding the nature of economic mobility during transition from socialist command economy to a more market oriented one. While China achieved extraordinary growth and poverty reduction over the last few decades, the growing inequality has become a focal point of concern for policy makers. Although cross-sectional inequality and intergenerational mobility are different concepts, as shown by Solon (2004), the link between the two is expected to be strong. Have the economic reforms that begun in 1978 such as household responsibility system, gradual relaxation of Hukou system (restrictions on geographic mobility), and 9 years of compulsory schooling policy (starting

\footnotetext{
${ }^{2}$ See, for example, Arrow et al. (2000)., Dearden et. al. (1997), Mulligan (1999), Solon (1999, 2002), Birdsall and Graham (1999), Fields et. al. (2005), Bowles et. al. (2005), Blanden et. al. (2005), WDR (2005), Mazumder (2005), Hertz (2005), Mookherjee and Ray (2006), Bjorklund et. al. (2006).

${ }^{3}$ Hertz et al (2007) provide a analysis of the basic correlations in educational attainment in a sample of 42 countries.

${ }^{4}$ We thus do not focus on different cohorts of children as is common in the literature on trends in intergenerational mobility (see, for example, Aaronson and Mazumder (2008)) .
} 
from 1986) expanded equality of economic opportunities in rural China? ${ }^{5}$ Or the market oriented reforms instead have generated inequalizing economic opportunities, thus making the 'accident of birth' increasingly more important in shaping the economic opportunities faced by an individual? ${ }^{6}$ Are there significant gender differences in intergenerational educational and occupational mobility in a given period and across time (over a period of 14 years) ? To the best of our knowledge, there is no rigorous analysis of the evolution of intergenerational economic mobility in rural China in the post reform period in the existing economics literature. ${ }^{7}$ We use two rounds of CHIP household survey data for the years 1988 and 2002 for the analysis of intergenerational persistence in educational attainment and occupational choices over a span of almost a decade and a half. The data in 1988 and 2002 are based on almost identical questionnaire (2002 round has some added information), and are comparable. This allows us to trace out the changes in intergenerational occupational and education persistence from 1988 to 2002.

The economics literature on the intergenerational economic mobility in developed countries focuses on income mobility, especially between father and son. ${ }^{8}$ There is also a relatively small literature on occupational mobility in labor economics, again mostly in the context of developed countries. $^{9}$ Similar to income mobility, the existing literature on occupational mobility focuses primarily on the father-son linkage (see Lentz and Laband (1983), and Dunn and Holtz-Eakin (2000) on U.S, Sjogren (2000) on Sweden, and Behrrman et. al. (2001) on Latin America). It is, however, not possible to focus on income or consumption mobility across generations in the context of most of the developing countries because of data unavailability. It is extremely difficult, if not impossible, to find data on income and consumption of the parental generation.

\footnotetext{
${ }^{5}$ Given the spectacular growth in income in rural China, one would expect a significant increase in parental investment in education, especially because the family is no longer dependent on the income from child labor (luxury axiom, a la Basu and Van (1998). The growth in per capita income in rural china has been impressive after the initiation of economic reform in 1978. Per capita income in rural China grew from 133.6 yuan in 1978 to 544.9 yuan in 1988 to 2475.6 yuan in 2002 .

${ }^{6}$ The existing Sociological literature on mobility in China find that economic mobility of the poor peasants were positively affected by the communist policies before the economic reform of 1978. References.

${ }^{7}$ The only paper we are aware of on educational mobility is by Sato and $\mathrm{Li}$ (2007) which analyzes the educational mobility among three generations of men in rural China using 2002 CHIP data set. In contrast, we focus on the changes, if any, in economic mobility in rural China with especial emphasis on the gender differences.

${ }^{8}$ The handful of studies examining the intergenerational correlations in earnings between mother and daughter include Chadwick and Solon (2002) for USA and Dearden, Machin and Reed (1997) for UK.

${ }^{9}$ The intergenerational occupational mobility has, however, been the the focus of a large, mostly descriptive, literature in sociology.
} 
In the face of such data limitations, we use education and occupation as two salient indicators of economic status for which the requisite data are available. There is a consensus in the current literature that educational mobility is among the most important components of intergenerational economic mobility, and it is especially important because it is amenable to policy interventions. ${ }^{10}$ Occupational mobility from agriculture to non-farm has also been identified as an important avenue to escape poverty traps, especially in the context of developing countries (Lanjou and Feder, 2001, and WDR, 2005). But the occupational persistence across generations in rural areas of developing countries remains especially under-researched; the only paper we are aware of is Emran and Shilpi (2011) that analyzes mobility out of agriculture into non-farm occupations in rural Nepal and Vietnam. ${ }^{11}$ In the context of China, the existing literature focuses on the role non-farm occupations plays in rural inequality with emphasis on short term migration. The role of human capital in facilitating entry into non-farm activities in rural China has also been the focus of a number of recent papers, see for example, Li et. al. (2005), de Brauw and Rozelle (2008) and Zhang et al (2008). The literature in general finds that education helps in rural non-farm participation.

There are a number of different channels through which intergenerational linkages in occupation and education can and do operate (for recent discussions, see Solon, 1999, Bowels, Gintis, and Osborne Groves (2005), and for the pioneering analysis of intergenerational mobility, see Becker and Tomes, 1976, 1979, and 1986). Some of the channels are tangible such as parental investment in children's education, bequests from parents and access to parent's social network. ${ }^{12}$ However, a significant part of the intergenerational correlations presumably arises from the effects of intangible factors such as genetic transmissions of ability and preference from parents to children, learning externalities (home tutoring in case of education and, learning by watching and informal apprenticeship in case of occupation), role model effects ${ }^{13}$ and transfer of reputation capital (likely

\footnotetext{
${ }^{10}$ More educated parents are more likely to work in non-farm and to have higher income and better access to credit. Thus they are more likely to be able to invest in human capital of children. The existing literature identifies expansion of publicly subsidized education as an important positive factor in improving economic mobility in a society (Hertz et al, 2007).

${ }^{11}$ Emran and Shilpi (2011) find that occupational mobility is much higher in Vietnam compared to Nepal.

${ }^{12}$ Bequests may relax credit constraint and thus induce children to start their own business in the non-farm sector.

${ }^{13}$ The definition of role model adopted so far in economic literature is not uniform. While Durlauf (2000) defines role model as the influence of "characteristics of older members" on the "preferences of younger members", Manski (1993) and Streufert (2000) define it as observations on older members whose choices reveal information relevant for
} 
to be especially important in occupation choices). However, the distinction between the tangible and intangible factors should not be overdrawn, as they are likely to interact in complex ways; for example, a more educated parent may invest more in children's education partly because their social capital can ensure a better return to education by exploiting their network in the labor market. Although our empirical analysis deals with both sources of intergenerational linkages, the focus is on understanding the effects of parental education and occupations that are not primarily driven by genetic correlations. The unobserved genetic correlations across generations can give rise to spurious intergenerational persistence, and this is the central identification challenge in understanding possible causal effects of parental education and occupation on children's education and occupation choices. The distinction between genetic and environmental influences on intergenerational linkages is important from a policy perspective; if the observed intergenerational persistence is driven primarily by genetic transmissions of ability and preference across generations, there is little role for policy interventions in promoting economic mobility in a society . In contrast, when the environmental factors are important, there are scopes for government policy interventions to alleviate persistent inequality in economic opportunities.

Although the economic literature on intergenerational mobility has been fraught with the difficulties in addressing the unobserved genetic correlations, our study enjoys an important advantage in this regard. We are interested in understanding the possible changes in the intergenerational linkages over a relatively short period of time (1988-2002); thus the direction of the change over time will be well identified under the plausible assumption that the genetic correlations do not change in any significant way in a span of 14 years. However, in the event that we find evidence of significant intergenerational linkages in a given year, we need to address the possibility that the estimated partial correlations between parents' and children's choices/outcomes are primarily driven by genetic correlations. To this end, we use a recently developed approach due to Altonji, Elder and Taber (2005) that relies on selection on observables as a guide to selection on unobservables (henceforth AET (2005)). We provide evidence on the sensitivity of the estimated intergenerational persistence with respect to different degrees of correlation between unobserved (genetic) characteristics of children and parents. The AET (2005) approach also allows us (i) to the choice of younger members. In this paper, we adopt a broad view that accommodates both of these definitions. 
estimate lower bounds on intergenerational links in education and occupations that cannot be driven by unobservable common genetic characteristics across generations, and (ii) to estimate the magnitude of selection on unobservable ability and preference. ${ }^{14}$

The evidence shows that the occupational mobility has increased dramatically from 1988-2002 for both sons and daughters, but educational mobility has remained largely static for daughters, and it has become stronger for sons over time. ${ }^{15}$ There is strong evidence of intergenerational occupational and educational persistence for both daughters and sons in 1988. The intergenerational persistence in occupational choice has vanished in 2002, but intergenerational persistence in educational attainment remains strong. For sons, the evidence indicates an increased intergenerational persistence in educational attainment in 2002 compared to 1998 and it seems to run along gender line (father-son). The evidence from AET (2005) sensitivity analysis using a biprobit model, and estimated lower bounds indicate that the observed persistence in educational attainment in 2002 is not likely to be driven by genetic transmissions alone, parental education seems to exert causal effects on children's (especially son's) educational attainment. The persistence in educational attainment across generations in 2002, after a decade and a half of 9 years compulsory education law seems puzzling. We provide some possible explanations for the dramatic divergence between the trends in intergenerational occupational and educational mobility from 1988 to 2002 .

The rest of the paper is organized as follows. Section 2 discusses the data and construction of variables. Section 3, arranged in a number of sub-sections, presents the empirical results. Section 4 concludes the paper.

\section{(2) The Data}

We use two rounds of Chinese Household Income Project (CHIP), 1988 to 2002 collected by a group of international and Chinese scholar with help from Chinese Academy of Social Science. We use the rural sub-sample for our analysis. We divide each year's sample into adult daughters sample and adult sons sample to examine the data separately, allowing us probe into gender relation more deeply. The adult children in this paper are defined as aged 18 years or older and

\footnotetext{
${ }^{14}$ For a recent application of AET (2005) approach to understanding intergenerational economic mobility, see the analysis of occupational mobility in rural Nepal and Vietnam by Emran and Shilpi (2011).

${ }^{15}$ We focus on mobility out of agriculture to non-farm activities as rural occupational mobility. There is substantial evidence that rural non-farm activities are avenues for poor households to escape from poverty traps. For general discussion, see Feder and Lanjou (2001).
} 
younger or equal to 60 years.

The CHIP surveys are repeated cross sections, and thus are suitable for an analysis of intergenerational mobility in the cross-section of the rural society in two different time points, 1988 and 2002 . The data sets were collected by the same research team using exactly the same sampling methodology. Even though the questionnaire in 2002 is richer compared with the 1988 survey, it is based on the 1988 questionnaire and include the same information. There is no separate parental module in the questionnaire. So the children in our sample are the children of the household head.

The 1988 data set contains 10,258 rural households in 29 provinces (or municipalities). The 2002 survey data covers 9,200 households in 22 provinces (or municipalities). Compared with 1988 data file, it does not cover two municipalities and seven provinces (autonomous regions) , which were covered previously in 1988. The adult children samples are as follows: 3231 (1988, daughters), 3363 (1988, sons), 2091 (2002 daughters), 3573 (2002, sons). The analysis of occupational persistence is done on the basis of these samples.

For the analysis of educational persistence, we only use the sample of children born in 1967 or later. This is done to make sure that the educational attainment was not directly disrupted by Cultural Revolution, which officially lasted from 1966 to 1976. So the adult children in our samples reached the age of 8 after 1975, which means they entered primary school either at the end of the Cultural Revolution, or after the Cultural Revolution. ${ }^{16}$ The samples for the education analysis are: 2057 (1988, daughters), 1884 (1988, sons), 2264 (2002, daughters), 3616 (2002, sons). The summary statistics of the explanatory variables for the full sample are presented in appendix Table A.1.

\section{(3) Empirical Results}

\section{(3.1) Educational Mobility}

\section{Stylized Correlations}

Table 1 presents the basic correlations in the data between parental education and children's educational attainment. The average years of schooling in 1988 is 5.8 years for daughters and

\footnotetext{
${ }^{16}$ Sato and Li $(2007 \mathrm{a}, 2007 \mathrm{~b})$ take a similar approach.
} 
6.8 years for sons, which increases to 9 years for both daughters and sons in 2002. The evidence thus clearly indicates that the educational attainment in rural China has improved significantly over the 14 years, and more strikingly the initial gender gap in education has vanished by 2002 .

The correlations between parents' years of schooling and children's schooling reported in Panel B of Table 1 show interesting patterns across gender and over time. The correlation in years of schooling between mother-daughter is 0.36 in 1988 , and it decreases to 0.30 in 2002 . The correlation between father-daughter on the other hand remains unchanged at 0.30 . The correlation in schooling between father-son is 0.26 in 1988 which is significantly smaller than that between mother-daughter for the same year. The correlation between father-son increases to 0.29 in 2002 . The mother-son correlation in schooling is 0.20 in 1988 and it increases to 0.26 in 2002. The basic correlations in the data thus indicate three broad patterns: (i) the intergenerational educational persistence was strong in case of daughters at the beginning of the period, and it does not show unambiguous trend over time; while the father-daughter link has remained unchanged, the link between mother-daughter is weaker in 2002, (ii) the intergenerational educational persistence was much weaker for sons in 1988, but over the span of 14 years, the correlations have become stronger and comparable to the correlations for daughters in 2002, (iii) the cross-gender correlations (mother-son and father-daughter) were much weaker in 1988, but in 2002, they are similar in terms of magnitude to the correlations along gender lines (mother-daughter, and father-son). Taken together, the correlations reported in Table 1 suggest that a remarkable gender convergence in education seems to have taken place in rural China by 2002.

The correlation between mother-father in schooling attainment was 0.41 in 1988 and it remains unchanged in 2002, indicating strong and stable assortative matching in the marriage market for the parental generation over time. It is also interesting that the correlation between father-mother is very similar across daughters' and sons' samples.

Panel $\mathrm{C}$ of Table 1 reports the basic intergenerational correlations using primary schooling (6 years schooling in China) as a threshold. For daughters generation in 1988, the probability that a woman has more than primary education is 0.34 when none of the parents has higher than primary schooling, it increases dramatically to 0.57 when at least one parent has higher than primary schooling; the probability becomes even higher when both parents have higher than 
primary schooling (0.79). A daughter's probability of attaining more than primary schooling conditional on mother having more than primary is 0.70 in 1988 , and sons probability conditional on father having more than primary education is 0.74. By 2002, the probability of having higher than primary schooling has increased dramatically for every woman irrespective of the parental educational status, but interestingly the advantage enjoyed by a daughter of more educated parents remains virtually unchanged, she is approximately 20 percentage points more likely to attain higher than primary education. The patterns of intergenerational correlations over time and across parent's education status in sons sample are similar to that observed in daughters sample.

\section{Econometric Analysis}

Most of the existing econometric analysis on intergenerational educational mobility focuses on years of schooling as a measure of educational attainment. However, a core part of our econometric analysis deals with binary measures of educational attainment, because this allows us to take advantage of a rich set of econometric techniques developed by Altonji et al (2005) to assess the importance of genetic correlations in ability and preference for the estimated intergenerational persistence. For the basic regression analysis, we report results for both the binary measures and years of schooling as indicators of educational attainment.

Starting with a simple bivariate specification with no other controls, we report a series of OLS and Probit regressions with increasingly richer sets of controls. They provide suggestive evidence on the strength of selection on observables, i.e., possible roles played the observable household and individual characteristics in determining the strength of the link between parental education and children's education. The control variables are observable characteristics that can proxy for ability and preference heterogeneity of parents and children. Under the assumption that selection on unobservables is similar to selection on observables, the sensitivity of the estimated intergenerational educational persistence with respect to the observables can also be informative about the possible strength of selection on unobservables (for a discussion, see Altonji et al (2005)).

\section{Results with Years of Schooling as a Measure of Educational Attainment}

Table 2 reports the estimated intergenerational persistence in years of schooling for alternative sets of control variables. Panel A shows the estimates for average schooling of parents in the household, and Panel B looks at the effects of mother's and father's schooling separately. 
The first three columns in Panel A of Table 2 show that the estimated intergenerational persistence in schooling for daughters is not sensitive to the inclusion of a set of individual and parental characteristics in both 1988 and 2002. This evidence can be interpreted as suggesting that selection at the individual level may not be of first order importance for the intergenerational schooling link. In contrast, when we include controls for household and village characteristics, the estimates decrease significantly (from 0.42 to 0.36 in 1988 and from 0.32 to 0.27 in 2002). The estimated intergenerational educational (partial) correlation in 1988 becomes much weaker when we add province ( 0.30 , see column 5$)$ and county fixed effects $(0.24$, see column 6$)$. Interestingly, the influence of province and county fixed effects has become much smaller for daughters in 2002, although the inclusion of the fixed effects still reduces the effect of parental schooling on a daughter's schooling. ${ }^{17}$ The county and province fixed effects capture the effects of locational heterogeneity on the estimate of intergenerational persistence. The geographic location may be capturing, for example, availability and quality of schools across different provinces, and across counties within a province (when county fixed effects are used), heterogeneity in access to urban labor markets (and thus in returns to education), among other things. Without these controls, one might find spurious effect of parental education on children's education simply because both are driven by, for example, persistent heterogeneity in labor market opportunities (nonfarm) across different geographic locations. Both parents and children may choose to become miners, because that is the only available opportunity in a mining town, and one would expect strong correlations in the educational attainment of miners working in the same mine. It would be misleading to attribute such persistence in education (or occupations) to family background or genetic inheritance.

The potential role of geographic location in determining the strength is interesting because migration in rural China has been restricted by Hukou system since 1951, and has been gradually relaxed, especially after 1993. Since it is likely that the parents or grand-parents chose the initial location before the imposition of Hukou system, the location can also be viewed as a summary statistic of unobserved heterogeneity (ability and preference) of parents and grand-

\footnotetext{
${ }^{17}$ Although the results using years of schooling as a measure of educational attainment show that province or county dummies have strong effect on the estimated intergenerational partial correlation in education, this pattern is not very robust, and is not found in case of binary measure of education or occupations. Although geography seems to still matter for the binary measures of education and occupation, its effect is not strong.
} 
parents. ${ }^{18}$ Given the restrictions on geographic mobility, it is also likely that the children with rural residence live in the same village (or the same county) as their parents, and thus the county fixed effects capture common labor market opportunities due to initial economic endowment of a county (for example, mineral resources, land productivity, climatic conditions etc). ${ }^{19}$

The estimates of the effects of parental schooling on a son's schooling reported in Panel A of Table 2 tell a story which is largely consistent with the correlations reported in Table 1, the strength of the intergenerational persistence in schooling for sons is lower than that for daughters in 1988 , but they have become comparable in $2002 .{ }^{20}$ The pattern of the estimates across different sets of controls is very similar to the pattern found in case of daughters. However, for sons in 2002, there is no difference in the estimated effect between columns (5) and (6) which indicates that heterogeneity across counties within a province is irrelevant for the extent of omitted variables bias in the estimated effect of parental schooling.

The estimates in column 6 of Table 2 show that the intergenerational persistence in educational attainment remains both numerically substantial and statistically significant in 1988 and 2002 even after we control for a rich set of individual, parental, household, village level variables along with county fixed effects. The controls used include age of child and both mother and father, and parents' occupation, are thus likely to pick up a good measure of the genetic endowment of children. As pointed out before, the changes in the educational persistence from 1988 to 2002 are unlikely to be due to changes in genetic correlations, as genetic traits do not change in any significant way in a decade and a half. We provide a more complete treatment of the possible role played by genetic correlations in the estimated intergenerational educational persistence later in the paper (see Tables 4 and 5 below).

\section{Who Matters for Children's Schooling ? Mother or Father, or Both?}

The results above focus on the effects of average parental schooling in a household. However, it is a common finding in the literature on intergenerational economic mobility that the correlations primarily run along gender lines (father-son and mother-daughter). ${ }^{21}$ We now turn to

\footnotetext{
${ }^{18}$ The adult children sample used in the paper is composed of individuals born after 1967 .

${ }^{19}$ Before 1998, a child would inherit the Hukou of his/her mother. After 1998, it can be either mother's or father's Hukou if they are different.

${ }^{20}$ This conclusion does not depend on the set of controls used across different columns in Table 2.

${ }^{21}$ In the context of USA, the role maternal education plays in children's education has been a subject of interesting
} 
possible differential effects of mother and father, and explore the issue of whether the correlations run primarily along gender lines. The measure of education is again years of schooling. The results reported in Panel B of Table 2 show the following broad patterns: (i) the intergenerational schooling correlations along gender lines (mother-daughter, and father-son) are stronger (compared to cross-gender effects) in 1988 across different columns in Table 2; the only exception is the case of sons when we use full set of controls with county fixed effect, (ii) in 2002, the correlation along gender line remains significantly stronger for sons (father-son), but it is no longer true for daughters. For daughters, the cross-gender effect is similar in magnitude to the own-gender effect in 2002 .

The estimates in Panel B of Table 2 also show interesting pattern over time. A comparison of different columns across 1988 and 2002 for sons shows that the increase in persistence in the intergenerational schooling correlation of sons is driven largely by the increasing correlation between father and son. In contrast, the correlation between mother and daughter has weakened a bit from 1988 to 2002, while the cross-effect between father and daughter has gone up over time (see column 6 of Table 2).

\section{Results with Binary Measures of Educational Attainment}

Table 3 reports estimated intergenerational persistence in educational attainment using binary measures of educational attainment. For the year 1988, we use primary schooling (6 years of schooling) as the threshold. But primary schooling is not appropriate as a threshold for children in 2002, as average years of schooling has gone up to 9 years (completion of junior high) in 2002 from about 6 years in 1988. We thus use junior high (9 years of schooling) as the threshold for children in 2002. Panel 3.A shows the results for the case when we focus on "at least one parent more than primary" as the measure of parental educational attainment, and Panel 3.B reports the results when we separate out mother's and father's educational attainment using primary schooling as the threshold.

The broad patterns in the results from binary measures of educational attainment are consistent with the pattern found for years of schooling in Table 2. In 1988, the persistence in education is much higher for daughters, but in 2002 they have become similar in terms of magnidebate (see, for example, Behrman and Rosenzweig (2002), and Goldberger and ?? AER). 
tude. According to the estimates including full set of controls and county fixed effects, in 1988, a daughter's probability of attaining more than primary schooling increases by about 16 percentage points, while a sons probability increases by 9 percentage points (see column 6 in Panel A of Table 3). The corresponding estimates for the year 2002 show interesting reversal, the effect of parental education on daughters has gone down to 12 percentage points, but the effect on sons has increased to 14 percentage points.

The pattern of estimates when we separate out mother's and father's effects are broadly similar to the ones from the estimates in Panel B of Table 2 for years of schooling and are not discussed for the sake of brevity.

\section{Can the Persistence in Educational Attainment Plausibly be Due to Ge- netic Correlations Alone? Evidence from AET (2005) Approach}

As discussed in the introduction, when one finds that the intergenerational linkages in economic status are numerically and statistically significant in multivariate regression analysis, as we find above in Tables 2 and 3, the estimated persistence can still be driven primarily (or solely) by transmission of genetic endowments from parents to children (both ability and preference transmission). If the observed intergenerational persistence is due to genetic correlations rather than economic environment, there is little or no role for any policy interventions to improve economic mobility in a society. To understand if the estimated intergenerational persistence shows a causal effect of parent's economic status on children's economic fortunes, the standard approach in economic literature would be to use instrumental variables. However, it is now well appreciated in the literature on intergenerational economic mobility that finding credible instruments is extremely difficult, if not impossible. Given the difficulties in finding credible instruments, researchers have appealed to alternatives such as using special samples of data (twins and adoptees) that can plausibly tackle the omitted variables bias created by unobserved genetic correlations (references). However, in the context of China, we are not aware of any data set on twins or adoptees over a period of a decade and a half in the post-reform period. To address the issue of spurious correlations due to unobserved genetic correlations, we take advantage of the recent approach developed by Altonji et al (2005) where selection on observables is used as a guide to 
selection on unobservables. ${ }^{22}$ The AET (2005) approach also allows us to estimate lower bounds on the intergenerational linkages that cannot be due to unobserved genetic correlations or any other common unobserved heterogeneity that affects the economic outcomes of both parental and children's generations.

\section{Sensitivity Analysis}

In this section, we use a bivariate probit model to explore the question whether a small amount of selection on unobservables can explain away the estimated partial correlations in education of parents and children in column (6) of Table 2. For the bivariate probit analysis, we use province fixed effects, as the model fails to converge with county fixed effects.

Consider the following bivariate probit model for individual $i$.

$$
\begin{aligned}
E_{i} & =1\left(\alpha E_{i}^{p}+X_{i}^{\prime} \gamma_{1}+\delta_{j} \omega_{j}+\xi>0\right) \\
E_{i}^{p} & =1\left(X_{i}^{\prime} \beta_{1}+\delta_{j} \omega_{j}+u>0\right) \\
{\left[\begin{array}{l}
u \\
\xi
\end{array}\right] } & \sim N\left[\begin{array}{l}
0 \\
0
\end{array}\right],\left[\begin{array}{ll}
1 & \rho \\
\rho & 1
\end{array}\right]
\end{aligned}
$$

where $E_{i}$ and $E_{i}^{p}$ are binary measures of educational attainment of a child and the parents respectively, $\omega_{j}$ is the relevant fixed effect (at the county or province level) included to control for unobserved and observed community level determinants including schooling supply, labor market opportunities, agglomeration and peer effects. The error terms $\xi$ and $u$ represent the unobserved genetic factors for a child and her parents respectively that are relevant for their educational attainment. The correlation between $\xi$ and $u$ is denoted as $\rho$ which captures the common genetic correlations that can give rise to spurious intergenerational persistence in the absence of any causal effect of parental education. As noted by AET (2005), one can argue that the above bivariate probit model is identified from nonlinearity, but such identification without any exclusion restrictions is not credible. We thus treat the bivariate probit model underidentified by one parameter $(\rho)$. We estimate the magnitudes of intergenerational educational link for different

\footnotetext{
${ }^{22}$ For an application of AET (2005) approach to understand the role of genetic correlations in intergenerational persistence, see Emran and Shilpi (2011).
} 
values of the correlation $(\rho) .{ }^{23}$ The vector of explanatory variables $(X)$ is the same as that in the regression results presented in column (6) of Table $2 .{ }^{24}$ Note that $\rho$ represents only that part of genetic correlation across generations which influences the educational attainment alone, and thus is likely to be much smaller than the average genetic correlation between parents and children. ${ }^{25}$ Also, since we include a set of control variables to proxy for ability and preference of children and parents, $\rho$ represents only any remaining genetic influences relevant for educational attainment of both generations.

The results from sensitivity analysis are reported in Table 4. First, consider the results for 1988. The first column presents the estimated intergenerational educational persistence from univariate probit model which assumes that $\rho=0$; the estimates are 0.16 for daughters and 0.09 for sons (same as column 6 in Table 2). Since the central issue here is whether the estimated effect is due to positive selection on unobserved genetic endowment, we implement the sensitivity analysis only for positive values of $\rho$. Column 2 in table 4 reports the estimate for $\rho=0.05$ which implies that the child of a parent with higher educational attainment is five percentage points more likely to have higher educational attainment simply because of genetic transmissions. The estimate of intergenerational persistence in education goes down a bit in case of daughters, from 0.16 to 0.13 , but for sons it remains unchanged at 0.10 . The estimated effects remain statistically significant at 5 percent level for both sons and daughters. Consistent with a priori expectations, the estimates decline more when the value of $\rho$ is 0.10 ; the estimate is 0.10 for daughters and 0.07 for sons, but the estimate for sons is no longer statistically significant. The estimated effect parent's education on daughters educational attainment remains numerically and statistically significant even when the value of $\rho$ goes up to 0.15 . The results thus indicate that, in 1988, the observed effect of parent's education on a daughter's education is very robust, and is unlikely to be driven by low to moderate levels of selection on unobservable genetic endowments. In contrast, the link between parents and sons is relatively weaker, and it can be entirely explained

\footnotetext{
${ }^{23}$ In addition to unobserved genetic correlations, this would also capture any other common determinants of educational attainment across parental and children's generations.

${ }^{24}$ The main results reported in this paper are not sensitive to changes in the set of controls in column (6) of Tables 2, 3,6 and 7. The conclusions from the AET (2005) sensitivity analysis and lower bound estimates also remain intact.

${ }^{25}$ The average correlation between parents and children in IQ is 0.50. But this captures both the genetic and environmental effects (Plomin et al, 2001).
} 
away by low to moderate levels of common genetic influences.

The sensitivity results for the year 2002 show a different pattern compared to that in 1988; the intergenerational persistence in educational attainment seems to have become much stronger for sons in 2002, but it has remained largely static for daughters. The univariate probit estimates $(\rho=0)$ show that the marginal effects of parental education (having at least one parent with more than primary schooling) are similar for sons and daughters, with the effect on sons being slightly larger ( 0.14 for sons and 0.12 for daughters) in 2002. The second column shows that when $\rho=0.05$, the estimates decline from 0.12 to 0.09 for daughters and from 0.14 to 0.11 for sons. The estimates for the case when $\rho=.10$ are 0.07 for daughters and 0.09 for sons, and they are statistically significant at 1 percent level (the $t$ statistic is, however, much higher for sons). The results in Table 4 indicate that, for both sons and daughters, the estimated intergenerational link in educational attainment in the year 2002 are not wiped out by low to moderate levels of selection on genetically transmitted ability and preference, and the link for sons seems especially strong. The effect of parental education remains numerically substantial (0.06) and statistically significant $(t=3.60)$ for sons even with a $\rho=0.15$, but the effect for daughters becomes numerically small and statistically insignificant.

The overall results from sensitivity analysis thus indicate that (i) there is convincing evidence of an increasing intergenerational persistence in educational attainment of sons from 1988 to 2002, and (ii) the intergenerational persistence in education for daughters has remained largely unchanged over the same time period, and (iii) low to moderate levels of selection on unobservables cannot explain away the observed educational persistence, especially for sons.

\section{Lower Bounds on the Intergenerational Educational Persistence}

The sensitivity analysis reported in Table 4 and discussed above is interesting and illuminating, but it has its limitations. Because we do not have a good prior about the likely magnitude of the intergenerational correlation represented by the parameter $\rho$. As argued above, the magnitude of $\rho$ is not likely to be very high because of two reasons: (i) it captures only those genetic traits that are relevant for educational attainment of both generations, and (ii) the regressions already include a rich set of controls for heterogeneity across individuals and geographic locations. However, we do not know if a reasonable estimate of $\rho$ is 0.000001 , or 0.05 , or 0.10 or even higher? The estimate 
of $\rho$ one obtains readily from a bivariate probit estimation relies on nonlinearity for identification, and thus is not credible, a point discussed earlier.

We can, however, estimate a lower bound on the intergenerational link in educational attainment using the approach developed by AET (2005). Assuming that unobservables are similar to unobservables, AET (2005) shows that one can estimate a lower bound on the causal effect by imposing the condition that "selection on observables is at least as large as selection on unobservables". This approach also provides an estimate of $\rho$ which is likely to be more credible than the standard estimate that relies on nonlinearity for identification. In the case of bivariate probit model above (equations 1-3), the lower bound estimate of $\alpha$ can be derived by imposing the following condition:

$$
\rho=\frac{\operatorname{Cov}\left(Z^{\prime} \beta_{2}, Z^{\prime} \gamma_{2}\right)}{\operatorname{Var}\left(Z^{\prime} \gamma_{2}\right)} ; \beta_{2}=\left(\beta_{1}, \delta\right), Z=(X, \omega)
$$

The estimated lower bounds on the causal effect of parental education on the educational attainment of children for both 1988 and 2002 are reported in Table 5. The estimated lower bounds are very similar across 1988 and 2002, but there are important gender differences. The lower bound for sons is numerically larger and statistically significant at 5 percent level both in 1988 and 2002. In contrast, the lower bound on the intergenerational link for daughters is relatively small and also statistically not significant at 5 percent level for both years. The lower bound estimates thus can be interpreted as very strong evidence that the intergenerational persistence between sons and parents in rural China remains strong after 25 years of economic reform since 1978, and it is highly unlikely that the observed influence of parental education on sons' education is due to the genetic transmissions alone. The evidence indicates that the parental education play a causal role in educational attainment of sons. Although the lower bound estimates for daughters are relatively weak, this evidence cannot be interpreted as sufficient proof in favor of the conclusion that parental education does not exert a causal effect on daughters' education. By definition, the true causal effect lies somewhere above the lower bound. ${ }^{26}$ When one takes stock of all the evidence from OLS regressions in Table 2 to sensitivity analysis in Table 4 and lower

\footnotetext{
${ }^{26}$ In this sense, the lower bound estimates can be informative only if it turns out that there is a significant effect of parental education at the bound.
} 
bound estimates in Table 5, it seems difficult to escape the conclusion that the intergenerational persistence in daughters education has remained largely static after a decade and a half of economic reform from 1988 to 2002, and that it is unlikely that the observed link is entirely due to genetic transmissions (this later conclusion is especially consistent with the sensitivity analysis).

The Table 5 also reports estimates for the correlation coefficient $\rho$ estimated by using equation (4) above for daughters and sons across the two years. This estimate is derived under the restriction that selection on observables is equal to the selection on unobservables. The average estimate of $\rho$ is 13.5 for 1988 , and 16.5 for 2002. The highest estimate of $\rho$ is found for daughters in 1988 (0.18). The estimates for three of the four cases are close to each other, the only exception is the estimate for sons in 1988 which is relatively low (0.09). The estimates suggest that the magnitude of $\rho$ is likely to be in the range of 0.10-0.15 which does not seem implausible given that the estimate of correlation in general cognitive skills (IQ) across parents and children is in the range of 0.30-0.50 (Plomin et al, 2001), taking into account the contributions of both nature and nurture.

\section{(3.2) Occupational Mobility}

\section{Stylized Correlations}

Table 6 presents basic statistics on employment status of sons and daughters over time and conditional on occupational status of parents in a given year. Panel A reports the average nonfarm employment rates in our data set, panel B the simple correlations between parents' and children's, and also father's and mother's occupation choices (assortative matching), and Panel C the probability of non-farm employment for sons and daughters conditional on the occupational status of parents. We define non-farm occupations as non-agricultural occupations in the rural areas (called rural non-farm activities in the literature).Foot note on some major types of non-farm activities.

According to the estimates in panel A of Table 6, the (unconditional) probability of nonfarm participation in 1988 is 0.22 for sons and 0.15 for daughters. The probability of non-farm participation increases dramatically in 2002 , to 0.52 for sons and to 0.46 for daughters. The evidence thus indicates that (i) a significant shift in favor of non-farm sector has occurred in 
the occupational structure in rural China over a period of 14 years, and (ii) there is a persistent gender bias against women in non-farm occupations; a daughter is about 6-7 percent less likely to participate in the non-farm occupations both in 1988 and in 2002.

According to the estimates in panel $\mathrm{B}$ of Table 6, the correlations between mother-daughter and father-daughter in non-farm participation are 0.28 and 0.26 respectively in 1988 . The correlations weaken substantially to 0.15 (mother-daughter) and 0.07 (father-daughter) in 2002. There is a similar trend in the intergenerational occupational correlations for sons; the father-son correlation decreases by half, from 0.24 to 0.12 , and the mother-son correlation goes down from 0.22 to 0.11 over the span of 14 years. The simple (unconditional) correlations thus provide strong indications that persistence in intergenerational occupational choices has become much weaker in rural China over time. In contrast, the correlation between mother and father in occupation choices has remained largely unchanged both in the sons' (0.26 in 1988 and 0.27 in 2002) and daughters' samples (0.24 in 1988 and 0.27 in 2002). This probably reflects the stability of the assortative matching process in the marriage market over the study period in rural China. ${ }^{27}$

The estimates in panel $\mathrm{C}$ indicate that, for both daughters and sons, the choice of nonfarm occupation depends on parent's occupational status in an important way in 1988. We consider parental occupational status to be non-farm when at least one of the parents is employed in that sector. A daughter's probability of participation in non-farm sector is 0.33 when at least one of the parents is in non-farm, but it falls to only 0.09 when none of the parents work in the non-farm sector. Similar pattern also holds for sons in 1988. The influence of parental non-farm occupation has, however, become less important in 2002, although it is still more likely for a child to be in the non-farm occupations when at least one parent is also in the same sector.

\section{Econometric Analysis}

Following the approach adopted for the educational mobility results in Table 2 and 3 , we report the results on occupational persistence sequentially, starting from a simple Probit regression we introduce an array of control variables in subsequent steps. This helps to understand the sources of omitted variables bias and to demonstrate the robustness (or non-robustness) of intergenerational linkages in non-farm participation.

\footnotetext{
${ }^{27}$ It is also interesting that mother-father occupational correlation does not change across sons' and daughters' samples.
} 
The results from a series of Probit regressions are reported in Table $7 .^{28}$ The panel 7.A reports the results for the case when we define parental occupational status as non-farm if at least one parent is in the nonfarm sector, while panel 7.B reports the estimates for mother and father occupational status separately.

The pattern of sensitivity of the estimated intergenerational persistence coefficient across different sets of control variables in panel 7.A is similar across gender, and interestingly, mimics well the pattern found earlier in case of intergenerational educational persistence, especially for the binary measures in Table 3. The estimated marginal effect of having at least one parent in nonfarm sector in 1988 is about 0.25 for both sons and daughters when no controls are included in the regressions. The estimates barely change when we include a set of individual and parental characteristics such as age, and ethnicity. However, when we include household and village characteristics (for example, availability of electricity and irrigation, and number of brothers and sisters), the estimate of intergenerational persistence declines substantially, from 0.22 to 0.16 for daughters and from 0.26 to 0.19 for sons (see columns 3 and 4). The estimates go down even more when we add province (column 5) and county (column 6) fixed effects. The pattern of the estimates across different columns for 2002 are very similar to that in 1988, especially for sons. For daughters, in 2002, parental characteristics seem to affect the magnitude of intergenerational occupational link in a significant way.

A comparison of estimates in panel 7.A show that the estimated effect of parental non-farm participation is almost identical across gender in 1988, and the it is somewhat larger for sons in 2002. The estimates indicate that parental occupational choices had had significant influence on children's occupation choices in 1988; even after controlling for a rich set of individual, parental, household, village characteristics along with county fixed effects, the estimates in column 6 imply that a son or daughter is 12 percentage point more likely to choose nonfarm occupation when at least one parent is in non-farm sector. But the most striking evidence in panel 7.A relates to the evolution of intergenerational persistence in occupation choices over 14 years from 1988 to 2002; the intergenerational link between parents and children in non-farm participation has completely vanished in 2002 , both for daughters and sons. For daughters, the coefficient on the

\footnotetext{
${ }^{28}$ The results from linear probability model are very similar and thus omitted for the sake of brevity.
} 
dummy for 'at least one parent in non-farm' turns negative and insignificant when we include individual, parental, household and village level controls, but no locational fixed effects are used. For sons, the strength of the intergenerational link is slightly higher, but it also does not survive when we include county fixed effects. The evidence thus shows that occupational mobility has dramatically improved in rural China; by 2002, a farmer's children are no longer doomed to be farmers themselves. In terms of occupational mobility, the transition to more market oriented open economy has been no less than magical in rural China.

The lower panel of Table 7 (7.B) shows the estimated effects of mother's and father's occupational choices on the occupation choices of children. Consistent with most of the literature on intergenerational occupational persistence, the intergenerational link runs along gender line for daughters; the effect of mother is much stronger compared to that of father in both 1988 and 2002. But somewhat unexpectedly, for sons, the cross-gender effect dominates, the father's effect is significantly smaller. Again, the most interesting and important evidence relates to the change in intergenerational linkages in occupation choices from 1988 to 2002 . While the effects of parents, especially of the mother are very strong in 1988 for both sons and daughters (see column 6 with full set of controls and county fixed effects), they have become either negative or very small when positive, and statistically insignificant in 2002. This confirms that occupational mobility out of agriculture has increased dramatically in rural China over the span of a decade and a half. The spectacular economic growth in the rural areas that started with the household responsibility system has completely changed the occupational opportunities faced by the younger generation of Chinese daughters and sons.

\section{Towards an Understanding of the Divergent Trends in Educational and Occupational Mobility}

An important finding from our empirical analysis is that intergenerational occupational persistence in non-farm sector has effectively vanished in rural China in a span of 14 years. Another interesting aspect of the dramatic improvements in occupational mobility is that its benefits are distributed equally across gender. Such a dramatic improvement in occupational mobility for both sons and daughters in a span of a decade and a half is no less than magical. But the not 
so magical part of the transition to a more market oriented economy in rural China is that the educational mobility has not improved over the same period of time. The evidence in fact suggest strongly that, if anything, the intergenerational persistence between sons and parents (and in particular between sons and fathers) has become stronger, implying lower mobility. While a complete treatment of possible reasons behind this divergence between occupational and educational mobility is beyond the scope of the present paper, we put forth a number of possible explanations behind the observed pattern in intergenerational persistence which can be explored in depth in future research.

One might expect that occupational mobility and educational mobility should go hand in hand in rural areas, especially given the evidence from recent research that probability of rural non-farm employment increases with education. However, note that most of the rural non-farm occupations do not require more than primary schooling, and the proportion of children with at least primary education was 97 percent for daughters and 100 percent for sons in 2002. So by 2002 education was not a constraining factor for most of the rural children for participation in non-farm activities. $^{29}$ The impressive productivity growth in agriculture following the implementation of household responsibility system meant that the rural households did not need the children to work on the farm to produce enough food; the children could explore alternative occupations without facing the prospect of quasi starvation. On the demand side, the spectacular growth of the non-farm sector fuelled by growth in the urban income and also expanding export market ensured that there was enough demand for rural non-farm products.

The lack of improvements (worsening in case of sons) in educational mobility can be traced to a host of factors including increased direct cost of education, and higher opportunity cost of continuing in the school. Although China adopted a legislation in 1986 for compulsory 9 years of education, its implementation has not been uniform, the rural areas has in general lagged behind (Behrman et al (2008), Tsang (1994, 2000)). The education reform focused on quality of education and shut down some low quality schools. Fiscal decentralization tightened the link between local economic conditions and educational opportunities in a village. Even though the

\footnotetext{
${ }^{29}$ This can also be demonstrated by looking at the probability of a child attaining primary schooling conditional on primary schooling of parents in 2002. By 2002, for attaining primary schooling, the parental education mattered little.
} 
central government provided transfers to the poor areas, the local governments in poor areas increasingly covered their costs by charging fees to their families. Tuition and fees increased from 4.42 percent of household expenditure in 1991 to 18.59 percent by 2004 (Behrman et al (2008)) $)^{30}$ The increased monetary costs of education naturally increased the persistence in educational attainment across generations; only the relatively rich in rural areas could afford education. After the economic reform in 1978, the relatively educated parents could take full advantage of the new opportunities both in agriculture and non-farm sector, and thus they reaped high income. ${ }^{31}$ This higher income allowed them to invest in children's education in the face of increasing private cost of schooling. The disadvantage faced by the children of less educated (and thus poorer) parents was reinforced by the rising returns to working in the rural non-farm sector (or urban migration); the opportunity costs of not working along with higher monetary costs of education made it difficult for them to continue schooling beyond a low threshold (primary schooling for example).

\section{(6) Conclusions}

Using two rounds of CHIP household survey data for 1988 and 2002, this paper provides evidence on the evolution of intergenerational economic mobility in rural China. It purports to answer the following question: if we compare two snapshots of the cross-section households in rural China has the rural society become more or less mobile from 1988 to 2002 ? In the absence of data on income or consumption for parental generation, we use educational attainment and occupational choices as two salient indicators of economic status in rural China.

A central issue in the literature on intergenerational persistence in economic status has been the possibility of spurious correlations driven by genetic transmissions from parents to children.

\footnotetext{
${ }^{30}$ For detailed and in-depth evidence on the importance of fees and related costs in schools of rural China, see Hannum (2008).

In a World bank report, Piazza and Liang (1998) conclude that "despite the extraordinary success in basic education in China, many poor were not reached by the government efforts...in the poorer half of the townships of 35 counties supported by a World Bank projects, average enrollment was at least $10 \%$ points lower than the national average for the same age group...".

${ }^{31}$ Yang (2004) shows that the more educated people were able to allocate their resources more efficiently under the household responsibility system. The returns to education was, in contrast, very low under collective agriculture before 1978 .
} 
Since our focus is on the changes in the intergenerational linkages over a period of a decade and a half, the estimated link between parents and children in education and occupations from multivariate regressions are likely to identify the direction of change in the intergenerational linkages reasonably well. To investigate the possible role played by genetic correlations across generations in determining the strength of intergenerational persistence in a given year, we take advantage of a battery of recently developed econometric techniques developed by Altonji, Elder and Taber (2005). The results from the empirical analysis show that the intergenerational occupational mobility has increased dramatically in rural China from 1988 to 2002. The effect of parental non-farm participation on children's non-farm choice is effectively zero for both daughters and sons in 2002. In contrast, the intergenerational educational persistence has remained largely static for daughters, while it has increased over time for sons. We provide some possible explanations for such divergence in occupational and education mobility in rural China in the post-reform period.

\section{References}

(1) Altonji, J, T.E. Elder and C.R. Taber (2005): "Selection on Observed and Unobserved Variables: Assessing the Effectiveness of Catholic Schools", Journal of Political Economy, 2005, Vol.113(1): 151-184.

(2) Altonji, J, T. Conley, T. Elder, and C. Taber (2005): "Methods for Using Selection on Observed Variables to Address Selection on Unobserved variables", March, 2005.

(3) Altonji, J, T. Elder, and C. Taber (2000): "Selection on Observed and Unobserved Variables: Assessing the Effectiveness of Catholic Schools", NBER WP. 7831.

(4) Altonji, J.G. and T. Dunn (2000): An Intergenerational Model of Wages, Hours, and Earnings, Journal of Human Resources, Vol. 35, n.2, 221-58.

(5) Arrow, K, S. Bowles, S. Durlauf (2000): Meritocracy and Economic Inequality, Princeton University Press.

(6) Bardhan, P (2005): Theory or Empirics in Development Economics, Economic and Political Weekly.

(7) Becker G. S. and N. Tomes (1979), "An Equilibrium Theory of the Distribution of Income and Intergenerational Mobility," Journal of Political Economy, vol. 87, no. 6. 
(8) Becker G. S. and N. Tomes (1986), "Human Capital and the Rise and Fall of Families," Journal of Labor Economics, vol.4, no.3, pt.2, S1-S39.

(9) Behrman, J. A. and M. Rosenzweig (2002): "Does Increasing Women's Schooling Raise the Schooling of the Next Generation?", American Economic Review, March, 2002.

(10) Behrman, J, A. Gaviria, M. Szekely (2003): Who's In and Who's Out: Social Exclusion in Latin America, Inter American Development Bank.

(11) Behrman, J., E. Hannum, M. Wang, and J. Liu (2008): Education in the Reform Era, in Brandt and T. Rawski Ed: China's Great Economic Transformation, Cambridge university Press.

(13) Bennet, L (2005): Gender, Caste and Ethnic Exclusion in Nepal, World Bank.

(14) Bevan, D, et. al. (1986): Trade Shocks in Controlled Economies, OUP, Oxford.

(15) Bjorklund, A, M Jantti, and G. Solon (2007): "Nature and Nurture in the Intergenerational Transmission of Socioeconomic Status: Evidence from Swedish Children and Their Biological and Rearing Parents", BE Journal of Economic Analysis and Policy (Advances), Issue 2, 2007.

(16) Bjorklund, A, M. Lindahl, and E. Plug (2006): The Origins of Intergenerational Associations: Lessons from Swedish Adoption Data, Quarterly Journal of Economics, 121.

(17) Blanden, J, P. Gregg, S. Machin (2005): Intergenrational Mobility in Europe and North America, Center For Economic Performance Report, April, 2005.

(18) Boyd, R and P. J. Richerson (1985): Culture and the Evolutionary Process, University of Chicago Press.

(19) Bowles, S, H. Gintis, M. Osborne Groves (2005): Unequal Chances: Family Background and Economic Success, Priceton University Press.

(20) Birdsall, N and C. Graham (eds) (1999): New markets, New Opportunities? Economic and Social Mobility in a Changing World, Brookings Institution.

(21) Chadwick L. and G. Solon (2002), "Intergenerational Income Mobility among Daughters," American Economic Review, vol. 92, no. 1, 335-44.

(23) Dearden, L and S. Machin, and H. Reed (1997): Intergenerational Mobility in Britain, Economic Journal, January, pp.47-66.

(24) Dunn, C (2004): The Intergenerational Transmission of Lifetime Earnings, Unpublished 
Ph.D. dissertation, University of Michigan,

(25) Dunn, T. and D. Holtz-Eakin (2000), "Financial Capital, Human Capital, and the Transition to Self-Employment: Evidence from Intergenerational Links," Journal of Labor Economics, Vol. 18, no.2, 282-305.

(26) Emran, M. S and F. Shilpi (2011): "Intergenerational Occupational Mobility in Rural Economy: Evidence from Nepal and Vietnam", Journal of Human Resources, issue 2, 2011.

(28) Fields, G, D. Grusky, and S. Morgan (Eds) (2005): Mobility and Inequality: Frontiers of Research from Sociology and Economics, Stanford University Press.

(30) Goldberger, A. (1989), "Economic and Mechanical Models of Intergenerational Transmission," American Economic Review, vol. 79, no.3, 504-513.

(31) Griffiths, A, W. Gelbart, J. Miller, and R. Lewontin (1999): Modern Genetic Analysis, W. H. Freeman and Co., 1999.

(32) Hertz, T (2001): Education, Inequality and Economic Mobility in South Africa,Ph.D. Dissertation, University of Massachusetts.

(33) Hertz....(2007): BE Journal of Economic Analysis and Policy.

(34) Lam, D, and R. F. Schoeni (1993), "Effects of Family Background on Earnings and Returns to Schooling: Evidence from Brazil", Journal of Political Economy, 101, 710-740.

(35) Lanjouw, P. and G. Feder (2001), "Rural Non-farm Activities and Rural Development," Rural Strategy Background Paper \# 4, World Bank.

(36) Lentz, B.S., and D. N. Laband (1983), "Like Father, Like Son: Toward an Economic Theory of Occupational Following." Southern Economic Journal, vol. 50, no.2, 474-93.

(37) Lillard, L, and M. R. Kilburn (1995), "Intergenerational Earnings Links: Sons and Daughters", RAND, Labor and Population Program WP\# 95-17.

(38) Lillard, L and Willis (1995), , Journal of Human Resources.

(39) Mazumder, B (2005): Fortunate Sons: New Estimates of Intergenerational Mobility in U.S. Using Social Security Earnings Data, Review of Economics and Statistics, May.

(40) Morgan, S (2005): Past Themes and Future Prospects for Research on Economic and Social Mobility, in Fields, Gursky, and Morgan (eds) (2005).

(41) Mulligan, C. B. (1999), "Galton vs. the Human Capital Approach to Inheritance," 
Journal of Political Economy, vol. 107 (6 Part 2), S184-S224.

(42) Plomin, R, DeFries, J, P. McGuffin, G. McClearn, and (2001): Behavioral Genetics, Worth Publishers, New York, 4th Edition.

(43) Rosenbaum, P.R., 1995, Observational Studies, New York: Springler-Verlag.

(44) Rosenbaum, P.R., and D. B. Rubin, 1983, "Assessing Sensitivity to an Unobserved Binary Covariate in an Observational Study with Binary Outcome," Journal of Royal Statistical Society, Vol. 45(2): 212-18.

(45) Sato, Hiroshi and Shi Li. 2007a Class origin, family culture, and intergenerational correlation of education in rural China. IZA Discussion Paper series No. 2642, Institute for the Study of Labor (IZA), Bonn, Germany

(46) Sato, Hiroshi and Shi Li. 2007b. Revolution and Family in Rural China: influence of family background on current family wealth, IZA Discussion Paper Series No. 3233, Institute for the Study of Labor (IZA), Bonn, Germany.

(47) Sjogren, A (2000): Occupational Choice and Incentives: The Role of Family Backgrounds, Working paper No. 539, RIIE, Stockholm.

(48) Solon, G (2002): "Cross-Country Differences in Intergenerational Earnings Mobility", Journal of Economic Perspectives, Summer 2002.

(49) Solon, G (1999), "Intergenerational Mobility in the Labor Market," in O. Ashenfelter and D. Card eds Handbook of Labor Economics, Vol 3A, Elsevier Science, North-Holland, Amsterdam.

(50) Streufert, P. (2000), "The Effect of Underclass Social Isolation on Schooling Choice," Journal of Public Economic Theory, vol. 2, no.4, 461-82.

(51) Thomas, D. (1994), "Like Father, Like Son; Like Mother, Like Daughter: Parental Resources and Child Height," Journal of Human Resources, vol. 29, no. 4, 950-88.

(52) World Development Report (WDR) (2005): Equity and Development, The World bank. 
Table 1: Descriptive statistics on education

Panel 1A: Average years of schooling

\begin{tabular}{cccccccccc}
\hline & \multicolumn{3}{c}{ Daughters sample } & \multicolumn{2}{c}{ Sons sample } & \multicolumn{3}{c}{ All sample } \\
Year & Daughter & Mother & Father & Son & Mother & Father & children & Mother & Father \\
\hline $\mathbf{1 9 8 8}$ & 5.8 & 2.4 & 5.2 & 6.8 & 2.3 & 5.0 & 6.3 & 2.4 & 5.1 \\
$\mathbf{2 0 0 2}$ & 9.0 & 5.3 & 7.1 & 9.0 & 4.9 & 6.9 & 9.0 & 5.0 & 7.0 \\
\hline
\end{tabular}

Panel 1B: Correlation in years of schooling

\begin{tabular}{|c|c|c|c|c|c|c|c|c|c|}
\hline \multirow[b]{2}{*}{ Year } & \multicolumn{3}{|c|}{ Daughters sample } & \multicolumn{3}{|c|}{ Sons sample } & \multicolumn{3}{|c|}{ All sample } \\
\hline & $\begin{array}{l}\text { Daughter } \\
\text { \& mother }\end{array}$ & $\begin{array}{l}\text { Daughter } \\
\text { \& father }\end{array}$ & $\begin{array}{c}\text { Mother \& } \\
\text { father }\end{array}$ & $\begin{array}{c}\text { Son } \\
\text { \& mother }\end{array}$ & $\begin{array}{c}\text { Son } \\
\text { \& father }\end{array}$ & $\begin{array}{c}\text { Mother \& } \\
\text { father }\end{array}$ & $\begin{array}{l}\text { Children } \\
\text { \& mother }\end{array}$ & $\begin{array}{l}\text { Children } \\
\text { \& father }\end{array}$ & $\begin{array}{c}\text { Mother \& } \\
\text { father }\end{array}$ \\
\hline 1988 & 0.36 & 0.30 & 0.42 & 0.20 & 0.26 & 0.41 & 0.28 & 0.27 & 0.41 \\
\hline 2002 & 0.30 & 0.30 & 0.42 & 0.26 & 0.29 & 0.40 & 0.27 & 0.29 & 0.41 \\
\hline
\end{tabular}


Panel 1C: Conditional correlations

\begin{tabular}{|c|c|c|c|c|}
\hline $\begin{array}{c}\text { Adult } \\
\text { children }\end{array}$ & $\begin{array}{l}\text { Both parents' education is less } \\
\text { than primary school }\end{array}$ & $\begin{array}{l}\text { At least one parent's education is } \\
\text { more than primary school }\end{array}$ & Difference & Person Chi2 \\
\hline \multicolumn{5}{|l|}{ Daughters } \\
\hline 1988 & 34.3 & 56.6 & 22.3 & 97.1 \\
\hline 2002 & 77.7 & 91.7 & 14.0 & 86.1 \\
\hline \multicolumn{5}{|l|}{$\underline{\text { Sons }}$} \\
\hline 1988 & 55.1 & 73.1 & 18.0 & 57.8 \\
\hline 2002 & 81.4 & 94.2 & 12.8 & 149.2 \\
\hline $\begin{array}{l}\text { Adult } \\
\text { children }\end{array}$ & $\begin{array}{l}\text { At least one parent's education } \\
\text { is less than primary school }\end{array}$ & $\begin{array}{l}\text { Both parents' education are more } \\
\text { than primary school }\end{array}$ & Difference & Person Chi2 \\
\hline \multicolumn{5}{|l|}{ Daughters } \\
\hline 1988 & 39.9 & 74.8 & 34.9 & 66.4 \\
\hline 2002 & 82.7 & 97.8 & 15.1 & 95.1 \\
\hline \multicolumn{5}{|l|}{$\underline{\text { Sons }}$} \\
\hline 1988 & 59.6 & 84.9 & 25.3 & 30.0 \\
\hline 2002 & 87.0 & 97.6 & 10.6 & 85.2 \\
\hline $\begin{array}{c}\text { Adult } \\
\text { children }\end{array}$ & $\begin{array}{l}\text { Mother's education is not more } \\
\text { than primary school }\end{array}$ & $\begin{array}{c}\text { Mother's education is more than } \\
\text { primary school }\end{array}$ & Difference & Person Chi2 \\
\hline \multicolumn{5}{|l|}{ Daughters } \\
\hline 1988 & 39.60 & 69.8 & 30.2 & 64.5 \\
\hline 2002 & 82.5 & 96.1 & 13.6 & 85.1 \\
\hline \multicolumn{5}{|l|}{$\underline{\text { Sons }}$} \\
\hline 1988 & 59.5 & 79.4 & 19.9 & 25.2 \\
\hline 2002 & 86.8 & 96.5 & 9.7 & 78.5 \\
\hline $\begin{array}{c}\text { Adult } \\
\text { children }\end{array}$ & $\begin{array}{l}\text { Father's education is not more } \\
\text { than primary school }\end{array}$ & $\begin{array}{c}\text { Father's education is more than } \\
\text { primary school }\end{array}$ & Difference & Person Chi2 \\
\hline \multicolumn{5}{|l|}{ daughters } \\
\hline 1988 & 34.9 & 56.7 & 21.8 & 89.9 \\
\hline 2002 & 78.7 & 92.1 & 13.4 & 83.8 \\
\hline \multicolumn{5}{|l|}{$\underline{\text { Sons }}$} \\
\hline 1988 & 55.5 & 73.8 & 18.3 & 57.2 \\
\hline 2002 & 82.3 & 94.6 & 12.3 & 141.6 \\
\hline
\end{tabular}

Note: Adult children's education dummy: 1=more than primary school 
Table 2: Impact of parents' years of schooling on children's years of schooling

Panel 2A: OLS result of impact of parents' average years of schooling (parents' years of schooling is average of parents' years of schooling)

\begin{tabular}{|c|c|c|c|c|c|c|}
\hline Adult children & $\begin{array}{c}\text { Parents' edu only } \\
\text { (1) }\end{array}$ & $\begin{array}{l}\text { Plus Ind. } \\
\text { (2) }\end{array}$ & $\begin{array}{l}\text { Plus parents } \\
\text { (3) }\end{array}$ & $\begin{array}{l}\text { Plus } \mathrm{HH} \text { and village } \\
\text { (4) }\end{array}$ & $\begin{array}{c}\text { Plus province } \\
\text { (5) }\end{array}$ & $\begin{array}{c}\text { Plus county } \\
\text { (6) }\end{array}$ \\
\hline \multicolumn{7}{|l|}{ 1988--daughters } \\
\hline Marginal Effect & 0.37 & 0.37 & 0.37 & 0.36 & 0.30 & 0.24 \\
\hline T statistics & 18.35 & 18.38 & 17.02 & 12.33 & 9.94 & 7.37 \\
\hline R square & 0.1391 & 0.1404 & 0.1707 & 0.2275 & 0.2881 & 0.4491 \\
\hline \multicolumn{7}{|l|}{ 1988--sons } \\
\hline Marginal Effect & 0.23 & 0.23 & 0.22 & 0.17 & 0.17 & 0.14 \\
\hline T statistics & 11.92 & 11.95 & 9.15 & 5.88 & 5.71 & 4.81 \\
\hline R square & 0.0731 & 0.0745 & 0.0963 & 0.1208 & 0.1451 & 0.3298 \\
\hline \multicolumn{7}{|l|}{ 2002-daughters } \\
\hline Marginal Effect & 0.32 & 0.32 & 0.32 & 0.27 & 0.24 & 0.20 \\
\hline T statistics & 16.09 & 15.95 & 14.64 & 12.76 & 11.07 & 8.85 \\
\hline R square & 0.1003 & 0.1079 & 0.1241 & 0.1923 & 0.2456 & 0.3331 \\
\hline \multicolumn{7}{|l|}{ 2002-sons } \\
\hline Marginal Effect & 0.33 & 0.31 & 0.27 & 0.24 & 0.22 & 0.22 \\
\hline T statistics & 20.86 & 19.53 & 15.56 & 13.50 & 12.15 & 11.37 \\
\hline R square & 0.1024 & 0.1099 & 0.1371 & 0.1689 & 0.2014 & 0.2449 \\
\hline
\end{tabular}

Note:

1) "Ind." stands for individual characteristics, including age and age squared;

2) "parents" stands for parental characteristics, including mother' age, father's age, parents in off-farming or not, parents' ethnic, and if parents is Communist Party member or cadre;

3)"HH and village" stands for household and village characteristics, including number of brothers and sisters,

female household head, land irrigated or not, log of land, log of house value, and access to electricity, type of terrain,

located in old revolutionary area, located in border area, ethnic minority region, suburb of large city, and in improvished county, and in coastal area

4) "province" stands for province fixed effect; "county" stands for county fixed effect

5) All regressions are corrected for heteroscedasticity 
Panel 2B: OLS result of impact of mother's years of schooling and father's years of schooling on children's years of schooling, respectively

\begin{tabular}{|c|c|c|c|c|c|c|c|c|c|c|c|c|}
\hline \multirow[t]{2}{*}{ Daughters } & \multicolumn{2}{|c|}{$\begin{array}{l}\text { Plus father's edu } \\
\text { (1) }\end{array}$} & \multicolumn{2}{|c|}{$\begin{array}{l}\text { Plus Ind. } \\
\text { (2) }\end{array}$} & \multicolumn{2}{|c|}{$\begin{array}{l}\text { Plus parents } \\
\text { (3) }\end{array}$} & \multicolumn{2}{|c|}{$\begin{array}{c}\text { Plus HH + Vilage } \\
\text { (4) }\end{array}$} & \multicolumn{2}{|c|}{$\begin{array}{l}\text { Plus province } \\
\text { (5) }\end{array}$} & \multicolumn{2}{|c|}{$\begin{array}{l}\text { Plus county } \\
\text { (6) }\end{array}$} \\
\hline & Mother & Father & Mother & Father & Mother & Father & Mother & Father & Mother & Father & Mother & Father \\
\hline \multicolumn{13}{|l|}{$\underline{1988}$} \\
\hline Marginal Effect & 0.25 & 0.15 & 0.25 & 0.15 & 0.26 & 0.17 & 0.22 & 0.14 & 0.19 & 0.12 & 0.14 & 0.10 \\
\hline T statistics & 12.33 & 7.04 & 12.37 & 7.01 & 12.22 & 7.21 & 9.23 & 5.67 & 7.41 & 5.02 & 5.14 & 4.01 \\
\hline R square & \multicolumn{2}{|c|}{0.1568} & \multicolumn{2}{|c|}{0.1584} & \multicolumn{2}{|c|}{0.1751} & \multicolumn{2}{|c|}{0.2312} & \multicolumn{2}{|c|}{0.2902} & \multicolumn{2}{|c|}{0.4529} \\
\hline \multicolumn{13}{|l|}{$\underline{2002}$} \\
\hline Marginal Effect & 0.17 & 0.19 & 0.17 & 0.19 & 0.18 & 0.17 & 0.16 & 0.15 & 0.13 & 0.15 & 0.11 & 0.13 \\
\hline T statistics & 9.73 & 9.69 & 9.93 & 9.57 & 9.91 & 8.28 & 8.57 & 7.09 & 7.11 & 7.02 & 5.50 & 6.41 \\
\hline R square & \multicolumn{2}{|c|}{0.1274} & \multicolumn{2}{|c|}{0.1335} & \multicolumn{2}{|c|}{0.1462} & \multicolumn{2}{|c|}{0.2033} & \multicolumn{2}{|c|}{0.2587} & \multicolumn{2}{|c|}{0.3497} \\
\hline \multirow[t]{2}{*}{ Sons } & \multicolumn{2}{|c|}{ Plus mother's edu } & \multicolumn{2}{|c|}{$\begin{array}{l}\text { Plus Ind. } \\
\text { (3) }\end{array}$} & \multicolumn{2}{|c|}{$\begin{array}{l}\text { Plus parents } \\
\text { (4) }\end{array}$} & \multicolumn{2}{|c|}{$\begin{array}{c}\text { Plus HH + Vilage } \\
\text { (5) }\end{array}$} & \multicolumn{2}{|c|}{$\begin{array}{l}\text { Plus province } \\
\text { (6) }\end{array}$} & \multicolumn{2}{|c|}{$\begin{array}{l}\text { Plus county } \\
\text { (6) }\end{array}$} \\
\hline & Father & Mother & Father & Mother & Father & Mother & Father & Mother & Father & Mother & Father & Mother \\
\hline \multicolumn{13}{|l|}{$\underline{1988}$} \\
\hline Marginal Effect & 0.16 & 0.08 & 0.16 & 0.08 & 0.14 & 0.08 & 0.10 & 0.07 & 0.10 & 0.07 & 0.07 & 0.07 \\
\hline T statistics & 7.83 & 4.74 & 7.85 & 4.76 & 6.29 & 4.45 & 3.92 & 3.24 & 3.84 & 3.11 & 2.81 & 2.69 \\
\hline R square & \multicolumn{2}{|c|}{0.0784} & \multicolumn{2}{|c|}{0.0801} & \multicolumn{2}{|c|}{0.0974} & \multicolumn{2}{|c|}{0.1212} & 0.1 & 434 & 0.33 & 314 \\
\hline$\underline{2002}$ & & & & & & & & & & & & \\
\hline Marginal Effect & 0.21 & 0.13 & 0.20 & 0.13 & 0.17 & 0.13 & 0.15 & 0.1 & 0.16 & 0.08 & 0.16 & 0.07 \\
\hline T statistics & 12.43 & 9.15 & 12.15 & 8.53 & 9.63 & 7.11 & 8.98 & 6.76 & 9.17 & 5.19 & 9.11 & 4.29 \\
\hline R square & 0.1 & 062 & 0.1 & 131 & 0.1 & 441 & 0.17 & 755 & 0.2 & 111 & 0.25 & 598 \\
\hline
\end{tabular}

Note:

1) "Ind." stands for individual characteristics, including age and age squared;

2) "parents" stands for parental characteristics, including mother' age, father's age, parents in off-farming or not, parents' ethnic, and if parents is Communist Party member or cadre;

3)"HH and village" stands for household and village characteristics, including number of brothers and sisters, female household head, land irrigated or not, log of land, log of house value, and access to electricity, type of terrain, located in old revolutionary area, located in border area, ethnic minority region, suburb of large city, and in improvished county, and in coastal area

4) "province" stands for province fixed effect; "county" stands for county fixed effect

5) All regressions are corrected for heteroscedasticity 
Table 3: Probit regression of parents' binary education level on children's binary education level

Panel 3A: Impact of parents' education level (parents' education dummy==1 if at least one parent's education is more than primary school)

\begin{tabular}{|c|c|c|c|c|c|c|}
\hline $\begin{array}{l}\text { Adult } \\
\text { Children }\end{array}$ & $\begin{array}{l}\text { Parents' edu only } \\
\text { (1) }\end{array}$ & $\begin{array}{l}\text { Plus Ind. } \\
\text { (2) }\end{array}$ & $\begin{array}{l}\text { Plus parents } \\
\text { (3) }\end{array}$ & $\begin{array}{l}\text { Plus } \mathrm{HH} \text { and village } \\
\text { (4) }\end{array}$ & $\begin{array}{l}\text { Plus province } \\
\text { (5) }\end{array}$ & $\begin{array}{l}\text { Plus county } \\
\text { (6) }\end{array}$ \\
\hline \multicolumn{7}{|l|}{ 1988--daughters } \\
\hline Marginal Effect & 0.23 & 0.23 & 0.20 & 0.17 & 0.16 & 0.16 \\
\hline T statistics & 10.17 & 10.15 & 8.44 & 6.34 & 5.89 & 4.93 \\
\hline Pseudo-R square & 0.0361 & 0.0368 & 0.0423 & 0.0852 & 0.1257 & 0.1964 \\
\hline \multicolumn{7}{|l|}{$\underline{1988-- \text { sons }}$} \\
\hline Marginal Effect & 0.17 & 0.17 & 0.14 & 0.11 & 0.10 & 0.09 \\
\hline T statistics & 7.49 & 7.49 & 5.47 & 3.78 & 3.44 & 2.49 \\
\hline Pseudo-R square & 0.0219 & 0.0222 & 0.0406 & 0.0689 & 0.0887 & 0.1581 \\
\hline \multicolumn{7}{|l|}{ 2002--daughters } \\
\hline Marginal Effect & 0.16 & 0.16 & 0.14 & 0.12 & 0.12 & 0.12 \\
\hline T statistics & 8.44 & 8.11 & 6.34 & 5.32 & 5.21 & 5.23 \\
\hline Pseudo-R square & 0.0242 & 0.0278 & 0.0404 & 0.0942 & 0.1182 & 0.1751 \\
\hline \multicolumn{7}{|l|}{ 2002--sons } \\
\hline Marginal Effect & 0.18 & 0.17 & 0.14 & 0.13 & 0.14 & 0.14 \\
\hline T statistics & 12.59 & 11.19 & 8.69 & 8.13 & 8.33 & 8.36 \\
\hline Pseudo-R square & 0.0336 & 0.0417 & 0.0697 & 0.0921 & 0.1057 & 0.1484 \\
\hline
\end{tabular}

Note

1) Adult children's education dummy: 1=more than primary school for 1988 sample

2) Adult children's education dummy: 1=more than middle school for 2002 sample

3) "Ind." stands for individual characteristics, including age and age squared;

4) "parents" stands for parental characteristics, including mother' age, father's age, parents in off-farming or not, parents' ethnic, and if parents is Communist Party member or cadre;

5)"HH and village" stands for household and village characteristics, including number of brothers and sisters,

female household head, land irrigated or not, log of land, log of house value, and access to electricity, type of terrain,

located in old revolutionary area, located in border area, ethnic minority region, suburb of large city, and in improvished county, and in coastal area

6) "province" stands for province fixed effect; "county" stands for county fixed effect 
Panel 3B: Impact of mother' education level and father's education level, respectively (mother's/father's education dummy==1 if mother's/father's education is more than primary school)

\begin{tabular}{|c|c|c|c|c|c|c|c|c|c|c|c|c|}
\hline \multirow[t]{2}{*}{ Daughters } & \multicolumn{2}{|c|}{$\begin{array}{l}\text { Parents' edu only } \\
\text { (1) }\end{array}$} & \multicolumn{2}{|c|}{$\begin{array}{l}\text { Plus Ind. } \\
\text { (2) }\end{array}$} & \multicolumn{2}{|c|}{$\begin{array}{l}\text { Plus parents } \\
\text { (3) }\end{array}$} & \multicolumn{2}{|c|}{$\begin{array}{c}\text { Plus HH + Vilage } \\
\text { (4) }\end{array}$} & \multicolumn{2}{|c|}{$\begin{array}{l}\text { Plus province } \\
\text { (5) }\end{array}$} & \multicolumn{2}{|c|}{$\begin{array}{l}\text { Plus county } \\
\text { (6) }\end{array}$} \\
\hline & Mother & Father & Mother & Father & Mother & Father & Mother & Father & Mother & Father & Mother & Father \\
\hline \multicolumn{13}{|l|}{1988} \\
\hline Marginal Effect & 0.23 & 0.18 & 0.23 & 0.18 & 0.22 & 0.16 & 0.19 & 0.15 & 0.18 & 0.14 & 0.19 & 0.15 \\
\hline T statistics & 5.63 & 7.58 & 5.62 & 7.56 & 5.30 & 6.50 & 4.12 & 5.21 & 3.63 & 4.96 & 3.47 & 4.46 \\
\hline Pseudo-R square & \multicolumn{2}{|c|}{0.0435} & \multicolumn{2}{|c|}{0.0441} & \multicolumn{2}{|c|}{0.0494} & \multicolumn{2}{|c|}{0.0898} & \multicolumn{2}{|c|}{0.1284} & \multicolumn{2}{|c|}{0.2007} \\
\hline \multicolumn{13}{|l|}{2002} \\
\hline Marginal Effect & 0.14 & 0.12 & 0.13 & 0.11 & 0.13 & 0.10 & 0.11 & 0.09 & 0.11 & 0.09 & 0.12 & 0.09 \\
\hline T statistics & 6.52 & 5.74 & 6.21 & 5.61 & 6.17 & 4.42 & 5.18 & 3.76 & 4.72 & 4.02 & 5.05 & 3.91 \\
\hline Pseudo-R square & \multicolumn{2}{|c|}{0.0376} & \multicolumn{2}{|c|}{0.0401} & \multicolumn{2}{|c|}{0.0524} & \multicolumn{2}{|c|}{0.1023} & \multicolumn{2}{|c|}{0.1253} & \multicolumn{2}{|c|}{0.1825} \\
\hline \multirow[t]{2}{*}{ Sons } & \multicolumn{2}{|c|}{$\begin{array}{l}\text { Parents' edu only } \\
\text { (1) }\end{array}$} & \multicolumn{2}{|c|}{$\begin{array}{l}\text { Plus Ind. } \\
\text { (2) }\end{array}$} & \multicolumn{2}{|c|}{$\begin{array}{l}\text { Plus parents } \\
\text { (3) }\end{array}$} & \multicolumn{2}{|c|}{$\begin{array}{c}\text { Plus HH + Vilage } \\
\text { (4) }\end{array}$} & \multicolumn{2}{|c|}{$\begin{array}{l}\text { Plus province } \\
\text { (5) }\end{array}$} & \multicolumn{2}{|c|}{$\begin{array}{l}\text { Plus county } \\
\text { (6) }\end{array}$} \\
\hline & Father & Mother & Father & Mother & Father & Mother & Father & Mother & Father & Mother & Father & Mother \\
\hline \multicolumn{13}{|l|}{$\underline{1988}$} \\
\hline Marginal Effect & 0.17 & 0.14 & 0.16 & 0.14 & 0.12 & 0.14 & 0.10 & 0.12 & 0.10 & 0.11 & 0.09 & 0.10 \\
\hline T statistics & 6.49 & 3.33 & 6.51 & 3.34 & 4.49 & 3.17 & 3.23 & 2.42 & 3.14 & 2.24 & 2.41 & 1.67 \\
\hline Pseudo-R square & \multicolumn{2}{|c|}{0.0281} & \multicolumn{2}{|c|}{0.0284} & \multicolumn{2}{|c|}{0.0444} & \multicolumn{2}{|c|}{0.0728} & & & & 519 \\
\hline$\underline{2002}$ & & & & & & & & & & & & \\
\hline Marginal Effect & 0.15 & 0.12 & 0.14 & 0.10 & 0.11 & 0.09 & 0.11 & 0.07 & 0.12 & 0.07 & 0.12 & 0.07 \\
\hline T statistics & 9.60 & 6.77 & 8.86 & 5.83 & 6.86 & 4.99 & 6.84 & 3.89 & 7.26 & 3.73 & 7.29 & 3.88 \\
\hline Pseudo-R square & & & & & & 739 & 0.0 & 951 & & & & 502 \\
\hline
\end{tabular}

Note

1) Adult children's education dummy: 1=more than primary school for 1988 sample

2) Adult children's education dummy: 1=more than middle school for 2002 sample

3) "Ind." stands for individual characteristics, including age and age squared;

4) "parents" stands for parental characteristics, including mother' age, father's age, parents in off-farming or not,

parents' ethnic, and if parents is Communist Party member or cadre;

5)"HH and village" stands for household and village characteristics, including number of brothers and sisters,

female household head, land irrigated or not, log of land, log of house value, and access to electricity, type of terrain,

located in old revolutionary area, located in border area, ethnic minority region, suburb of large city, and in improvished county,

and in coastal area

6) "province" stands for province fixed effect; "county" stands for county fixed effect

7) All regressions are corrected for heteroscedasticity 
Table 4: Sensitivity analysis: marginal effect of parents' education level on children's education level

\begin{tabular}{|c|c|c|c|c|c|c|c|}
\hline \multirow{2}{*}{ Sample } & \multirow{2}{*}{ Year } & \multicolumn{6}{|c|}{ Correlation of disturbance } \\
\hline & & $\rho=0$ & $\rho=0.05$ & $\rho=0.05$ & $\rho=0.15$ & $\rho=0.20$ & $\rho=0.25$ \\
\hline & 1988 & $\begin{array}{c}0.16 \\
(5.89)^{* * *}\end{array}$ & $\begin{array}{c}0.13 \\
(4.70)^{* * *}\end{array}$ & $\begin{array}{c}0.10 \\
(3.51)^{* * *}\end{array}$ & $\begin{array}{c}0.06 \\
(2.32)^{* *}\end{array}$ & $\begin{array}{c}0.03 \\
(1.11)\end{array}$ & $\begin{array}{l}-0.003 \\
(-0.12)\end{array}$ \\
\hline & 2002 & $\begin{array}{c}0.12 \\
(5.21)^{* * *}\end{array}$ & $\begin{array}{c}0.09 \\
(4.25)^{* * *}\end{array}$ & $\begin{array}{c}0.07 \\
(3.03)^{* * *}\end{array}$ & $\begin{array}{c}0.04 \\
(1.79)^{*}\end{array}$ & $\begin{array}{c}0.01 \\
(0.53)\end{array}$ & $\begin{array}{l}-0.020 \\
(-0.75)\end{array}$ \\
\hline & 1988 & $\begin{array}{c}0.1 \\
(3.44)^{* * *}\end{array}$ & $\begin{array}{c}0.09 \\
(2.57)^{* * *}\end{array}$ & $\begin{array}{c}0.07 \\
(1.59)\end{array}$ & $\begin{array}{c}0.02 \\
(0.58)\end{array}$ & $\begin{array}{c}-0.02 \\
(-0.73)\end{array}$ & $\begin{array}{l}- \\
-\end{array}$ \\
\hline S & 2002 & $\begin{array}{c}0.14 \\
(8.33)^{* * *}\end{array}$ & $\begin{array}{c}0.11 \\
(6.79)^{* * *}\end{array}$ & $\begin{array}{c}0.09 \\
(5.20)^{* * *}\end{array}$ & $\begin{array}{c}0.06 \\
(3.60)^{* * *}\end{array}$ & $\begin{array}{c}0.03 \\
(1.57)\end{array}$ & $\begin{array}{l}0.005 \\
(0.31)\end{array}$ \\
\hline
\end{tabular}

Note:

1)t statistics in parentheses;

2) Adult children's education dummy: 1=more than primary school for the 1988 sample;

3) Adult children's education dummy: 1=more than middle school for the 2002 sample;

4) Parent's education dummy, $=1$ if at least one parent's education is more than primary school;

5) “*” significant at 10 percent; “**” significant a 5 percent; “***” significant at 1 percent 
Table 5: Marginal effect of parents' education under convergence of biprobit probit model

\begin{tabular}{ccccc}
\hline \multirow{2}{*}{ Sample } & Year & $\rho$ & $\alpha$ & T statistics \\
\hline \multirow{2}{*}{ Daughters } & 1988 & 0.18 & 0.04 & 1.42 \\
& 2002 & 0.16 & $\mathbf{0 . 0 4}$ & 1.66 \\
& 1988 & 0.09 & $\mathbf{0 . 0 7}$ & 2.73 \\
Sons & 2002 & 0.15 & $\mathbf{0 . 0 6}$ & 3.57 \\
\hline
\end{tabular}


Table 6: Descriptive statistics on occupation

Panel 6A: Probability to participate in off-farming

\begin{tabular}{ccccccccccc}
\hline & \multicolumn{3}{c}{ Daughters sample } & & \multicolumn{2}{c}{ Sons sample } & & \multicolumn{2}{c}{ All sample } \\
Year & Daughter & Mother & Father & Son & Mother & Father & children & Mother & Father \\
\hline 1988 & 0.15 & 0.04 & 0.21 & 0.22 & 0.04 & 0.20 & 0.18 & 0.04 & 0.21 \\
2002 & 0.47 & 0.08 & 0.34 & 0.52 & 0.08 & 0.29 & 0.50 & 0.08 & 0.30 \\
\hline
\end{tabular}

Panel 6B: Correlation in participation in off-farming activity

\begin{tabular}{|c|c|c|c|c|c|c|c|c|c|}
\hline \multirow[b]{2}{*}{ Year } & \multicolumn{3}{|c|}{ Daughters sample } & \multicolumn{3}{|c|}{ Sons sample } & \multicolumn{3}{|c|}{ All sample } \\
\hline & $\begin{array}{l}\text { Daughter } \\
\text { \& mother }\end{array}$ & $\begin{array}{l}\text { Daughter } \\
\& \text { father }\end{array}$ & $\begin{array}{c}\text { Mother \& } \\
\text { father }\end{array}$ & $\begin{array}{c}\text { Son } \\
\text { \& mother }\end{array}$ & $\begin{array}{c}\text { Son } \\
\& \text { father }\end{array}$ & $\begin{array}{c}\text { Mother \& } \\
\text { father }\end{array}$ & $\begin{array}{l}\text { Children } \\
\text { \& mother }\end{array}$ & $\begin{array}{l}\text { Children } \\
\text { \& father }\end{array}$ & $\begin{array}{c}\text { Mother \& } \\
\text { father }\end{array}$ \\
\hline 1988 & 0.28 & 0.26 & 0.24 & 0.22 & 0.24 & 0.26 & 0.24 & 0.24 & 0.25 \\
\hline 2002 & 0.15 & 0.07 & 0.27 & 0.11 & 0.12 & 0.27 & 0.13 & 0.10 & 0.27 \\
\hline
\end{tabular}


Panel 6C: Conditional correlations

\begin{tabular}{|c|c|c|c|c|}
\hline $\begin{array}{l}\text { Adult } \\
\text { children }\end{array}$ & $\begin{array}{l}\text { Neither parent has participated } \\
\text { in off-farming }\end{array}$ & $\begin{array}{l}\text { At least one parent has participated in } \\
\text { off-farming }\end{array}$ & Difference & Person Chi2 \\
\hline \multicolumn{5}{|l|}{ Daughters } \\
\hline 1988 & 9.4 & 33.2 & 23.8 & 252.8 \\
\hline 2002 & 43.0 & 52.3 & 9.3 & 16.5 \\
\hline \multicolumn{5}{|l|}{$\underline{\text { Sons }}$} \\
\hline 1988 & 16.4 & 41.7 & 25.3 & 207.8 \\
\hline 2002 & 47.4 & 60.9 & 13.5 & 55.5 \\
\hline $\begin{array}{l}\text { Adult } \\
\text { children }\end{array}$ & $\begin{array}{l}\text { At least one parent has } \\
\text { participated in off-farming }\end{array}$ & $\begin{array}{l}\text { Both parents have participated in off- } \\
\text { farming }\end{array}$ & Difference & Person Chi2 \\
\hline \multicolumn{5}{|l|}{ Daughters } \\
\hline 1988 & 13.1 & 71.1 & 58.0 & 233.6 \\
\hline 2002 & 44.6 & 72.8 & 28.2 & 37.6 \\
\hline \multicolumn{5}{|l|}{$\underline{\text { Sons }}$} \\
\hline 1988 & 20.2 & 73.9 & 53.7 & 152.1 \\
\hline 2002 & 50.2 & 75.7 & 25.5 & 46.5 \\
\hline $\begin{array}{l}\text { Adult } \\
\text { children }\end{array}$ & $\begin{array}{c}\text { Mother has not participated in } \\
\text { off-farming }\end{array}$ & Mother has participated in off-farming & Difference & Person Chi2 \\
\hline \multicolumn{5}{|l|}{ Daughters } \\
\hline 1988 & 12.80 & 64.1 & 51.3 & 257.4 \\
\hline 2002 & 44.1 & 72.7 & 28.6 & 48.8 \\
\hline \multicolumn{5}{|l|}{$\underline{\text { Sons }}$} \\
\hline 1988 & 20 & 66.5 & 46.5 & 156.8 \\
\hline 2002 & 50 & 70.8 & 20.8 & 42.9 \\
\hline $\begin{array}{l}\text { Adult } \\
\text { children }\end{array}$ & $\begin{array}{c}\text { Father has not participated in } \\
\text { off-farming }\end{array}$ & Father has participated in off-farming & Difference & Person Chi2 \\
\hline \multicolumn{5}{|l|}{ daughters } \\
\hline 1988 & 10.0 & 32.4 & 22.4 & 216.4 \\
\hline 2002 & 43.8 & 51.3 & 7.5 & 10.5 \\
\hline \multicolumn{5}{|l|}{$\underline{\text { Sons }}$} \\
\hline 1988 & 16.9 & 41.4 & 24.5 & 188.7 \\
\hline 2002 & 47.7 & 60 & 12.3 & 51.6 \\
\hline
\end{tabular}




\section{Table 7: Probit regression of impact of parents' occupation on children's occupation choice}

Panel 7A: Impact of parents' occupation (parents' occupation dummy=1 if at least one parent in offfarming activity)

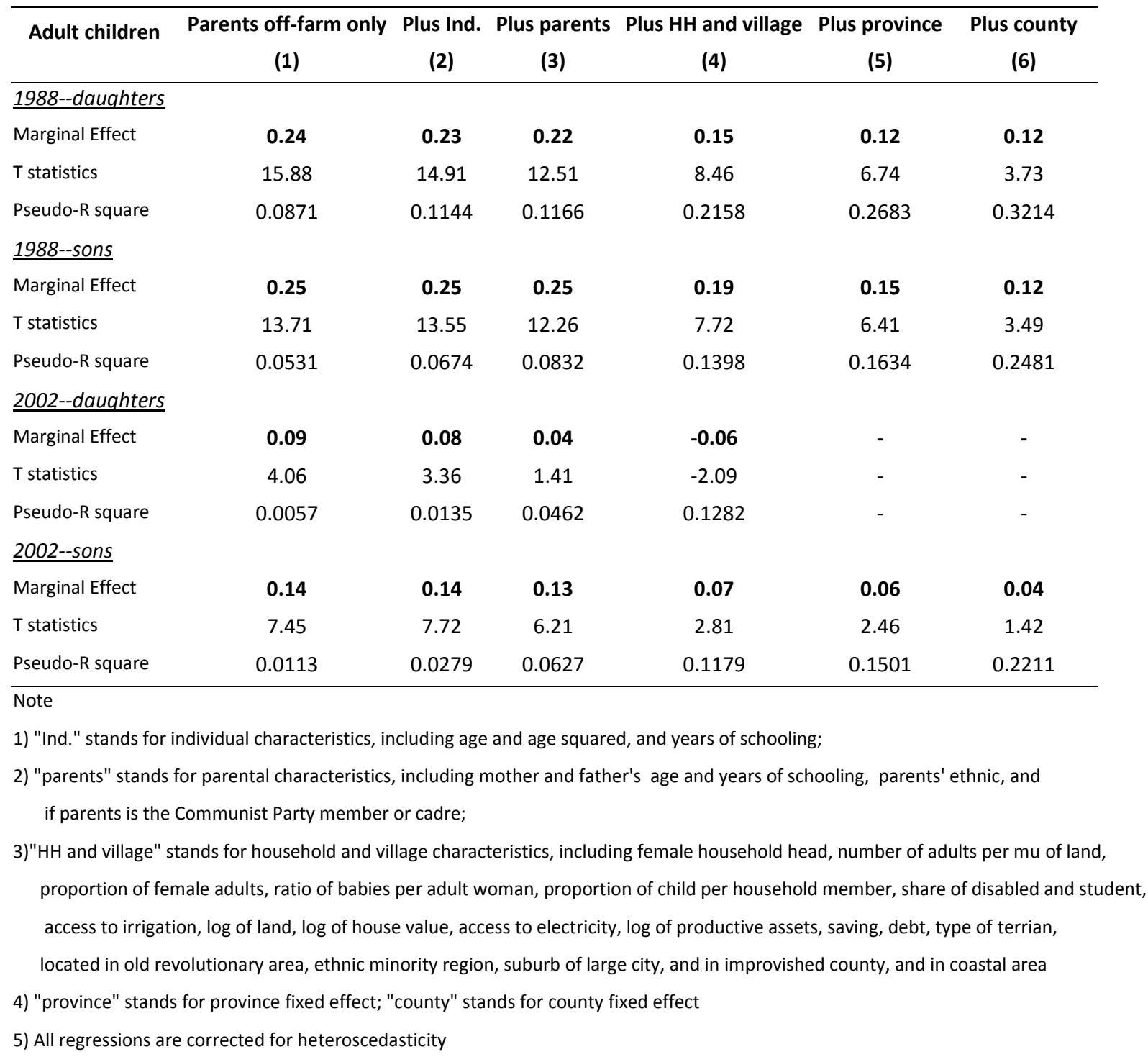


Panel 7B: Impact of mother's occupation and father's occupation on children's occupation choice, respectively

\begin{tabular}{|c|c|c|c|c|c|c|c|c|c|c|c|c|}
\hline \multirow[t]{2}{*}{ Daughters } & \multicolumn{2}{|c|}{$\begin{array}{l}\text { Parents' off-farm only } \\
\text { (1) }\end{array}$} & \multicolumn{2}{|c|}{$\begin{array}{l}\text { Plus Ind. } \\
\text { (2) }\end{array}$} & \multicolumn{2}{|c|}{$\begin{array}{l}\text { Plus parents } \\
\text { (3) }\end{array}$} & \multicolumn{2}{|c|}{$\begin{array}{c}\text { Plus HH + Vilage } \\
\text { (4) }\end{array}$} & \multicolumn{2}{|c|}{$\begin{array}{l}\text { Plus province } \\
\text { (5) }\end{array}$} & \multicolumn{2}{|c|}{$\begin{array}{l}\text { Plus county } \\
\text { (6) }\end{array}$} \\
\hline & Mother & Father & Mother & Father & Mother & Father & Mother & Father & Mother & Father & Mother & Father \\
\hline \multicolumn{13}{|l|}{$\underline{1988}$} \\
\hline Marginal Effect & 0.39 & 0.18 & 0.38 & 0.16 & 0.37 & 0.16 & 0.38 & 0.11 & 0.31 & 0.08 & 0.45 & 0.07 \\
\hline T statistics & 9.86 & 10.88 & 9.72 & 10.02 & 9.3 & 8.8 & 8.3 & 5.9 & 6.6 & 4.8 & 5.4 & 2.24 \\
\hline Pseudo-R square & \multicolumn{2}{|c|}{0.1062} & \multicolumn{2}{|c|}{0.1324} & \multicolumn{2}{|c|}{0.1418} & \multicolumn{2}{|c|}{0.2169} & \multicolumn{2}{|c|}{0.2857} & \multicolumn{2}{|c|}{0.3438} \\
\hline \multicolumn{13}{|l|}{$\underline{2002}$} \\
\hline Marginal Effect & 0.27 & 0.03 & 0.26 & 0.02 & 0.23 & -0.01 & 0.19 & - & 0.17 & - & 0.07 & - \\
\hline T statistics & 6.28 & 1.42 & 6.03 & 0.89 & 5.1 & -0.47 & 3.09 & - & 2.8 & - & 0.92 & - \\
\hline Pseudo-R square & \multicolumn{2}{|c|}{0.0181} & \multicolumn{2}{|c|}{0.0253} & \multicolumn{2}{|c|}{0.0555} & \multicolumn{2}{|c|}{0.11339} & \multicolumn{2}{|c|}{0.2012} & \multicolumn{2}{|c|}{0.2599} \\
\hline \multirow[t]{2}{*}{ Sons } & \multicolumn{2}{|c|}{ Parents' off-farm only } & \multicolumn{2}{|c|}{$\begin{array}{l}\text { Plus Ind. } \\
\text { (2) }\end{array}$} & \multicolumn{2}{|c|}{$\begin{array}{l}\text { Plus parents } \\
\text { (3) }\end{array}$} & \multicolumn{2}{|c|}{$\begin{array}{c}\text { Plus HH + Vilage } \\
\text { (4) }\end{array}$} & \multicolumn{2}{|c|}{$\begin{array}{l}\text { Plus province } \\
\text { (5) }\end{array}$} & \multicolumn{2}{|c|}{$\begin{array}{l}\text { Plus county } \\
\text { (6) }\end{array}$} \\
\hline & Father & Mother & Father & Mother & Father & Mother & Father & Mother & Father & Mother & Father & Mother \\
\hline \multicolumn{13}{|l|}{$\underline{1988}$} \\
\hline Marginal Effect & 0.20 & 0.35 & 0.20 & 0.34 & 0.21 & 0.33 & 0.15 & 0.32 & 0.13 & 0.26 & 0.11 & 0.31 \\
\hline T statistics & 10.57 & 7.93 & 10.51 & 7.72 & 9.5 & 7.3 & 5.9 & 5.6 & 5.2 & 4.3 & 3.1 & 3.4 \\
\hline Pseudo-R square & \multicolumn{2}{|c|}{0.0664} & \multicolumn{2}{|c|}{0.0809} & \multicolumn{2}{|c|}{0.0957} & \multicolumn{2}{|c|}{0.1479} & & & & 541 \\
\hline$\underline{2002}$ & & & & & & & & & & & & \\
\hline Marginal Effect & 0.11 & 0.17 & 0.12 & 0.17 & 0.1 & 0.15 & 0.07 & 0.04 & 0.06 & 0.04 & 0.04 & -0.007 \\
\hline T statistics & 5.68 & 4.93 & 5.94 & 5.2 & 4.9 & 4.3 & 2.84 & 0.93 & 2.56 & 0.85 & 1.52 & -0.15 \\
\hline Pseudo-R square & & & 0.03 & & 0.0 & 663 & 0.11 & 185 & & 506 & & 211 \\
\hline
\end{tabular}

\section{Note}

1) "Ind." stands for individual characteristics, including age and age squared, and years of schooling;

2) "parents" stands for parental characteristics, including mother and father's age and years of schooling, parents' ethnic, and if parents is the Communist Party member or cadre;

3)"HH and village" stands for household and village characteristics, including female household head, number of adults per mu of land, proportion of female adults, ratio of babies per adult woman, proportion of child per household member, share of disabled and student, access to irrigation, log of land, log of house value, access to electricity, log of productive assets, saving, debt, type of terrian, located in old revolutionary area, ethnic minority region, suburb of large city, and in improvished county, and in coastal area

4) "province" stands for province fixed effect; "county" stands for county fixed effect

5) All regressions are corrected for heteroscedasticity 